\title{
Reorientation of Values of The Indonesian Diversity (ke-Bhineka-an Indonesia) to Reaffirming the National Identity
}

\author{
Tetep Tetep \\ Institut Pendidikan Indonesia \\ Garut, Indonesia \\ tevs_gaya@yahoo.co.id
}

\begin{abstract}
Indonesia was born as an independent state based on plurality like as, culture, ethnicity, religion and race as the power of the birth of NKRI in the pledge of Youth Pledge. Currently the Indonesian is being tested identity and ideology of nationalism with the increasingly widespread cases of intolerance, violence, terrorism, blasphemy and other cases. The euphoria of democracy after the human rights values had been ignored in the Orde Baru era triggered the openness of freedom that seemed without limited so that the fading of democratic values in accordance with the culture and soul of the Indonesian. The main effort is how to re-awaken the spirit of Indonesia on diversity as the foundation of the birth of NKRI so that the values of tolerance, mutual respect and appreciation becomes a force in realizing the Unity of Indonesia. This research was conducted on the students at PPKn STKIP Garut with as sample of 40 people and described how to teach about 1) Media Literacy, 2) Deep Teaching of Pancasila and Civic Education values, and 3) Integrated of Local Culture. Through descriptive study research result indication that: 1) Use of Technology well efforts to students to wisely action $75,5 \%$. 2) To Teaching Values of Pancasila and Civic Education by well reinforce to the national identity, $66,5 \% 3$ ) by the Integrated the values of local cultural differences can be improved understand of students to diversity values $85,4 \%$. By utilizing the wise of the technology and information media, it can be strengthening the diversity values to maintain unity so that the national identity is not uprooted and the local culture remains the national foundation.
\end{abstract}

\section{Keywords-identity; Indonesian diversity; nasionalism}

\section{INTRODUCTION}

Since 700 years ago Indonesia has been known as a diverse country or diverse in accordance with the motto "Bhinneka Tunggal Ika". Pluralism is then become a tremendous wealth, but also a challenge or threat to the sustainability of this nation in the future. One of the threats of national pluralism is the emergence of issues related to SARA (Ethnic and Religion Conflict). Prolonged conflict becomes one of the serious threats to the nation of Indonesia if all parties are not wisely to taking action and decisions.

Diversity or plurality in the terms of the Cambridge Dictionary is called Pluralism which has the meaning of "the existence of different types of people, who have different beliefs and opinions, within the same society". Differences and pluralism in a society or nation whether viewed from tribes, races, and religions or even differences of opinion to be the founder of pluralism in the life of the Indonesian Nations referred to as the Decreet and Design of God that The Indonesia nation cannot be monolithic but pluralist [1]. As Lene Pederson described in the journal The Asia Pacific Journal of Anthropology explains that: "Indonesia is one of the world's great plural societies" [2]. With this pluralistic haze, it makes a tremendous challenge for the Indonesian nation, since plurality may pose many threats to the nation's unity and the national identity, especially if this plural nation has abandoned its nation's historical values.

The consciousness of nationalism is critical, rational, dialectical, proactive, and holistic thinking about the future of the nation based on current experience and based on past experience [3]. The history of a nation is the creation of the nation itself, not the creation of another nation. Such awareness is the basis for building a better future of the nation in the past and the present. The identity of nationalism needs to be strengthened amid the pluralism of this nation and the challenges of today's global world so it needs to build awareness of the spirit of nationality even in the midst of diversity and diversity. The proof of the challenge of this increasingly diverse global world for the Indonesian nation is the role of cyberspace that is increasingly fading the borders of the state and nation.

One of A newspaper published in Jakarta (25/10/2009) conducts a survey of youth (ages 16-30 years): $70 \%$ prefer social interaction multiply friends or networks through cyberspace than the real world, $24 \%$ choose to join a political party or youth organizations, and $6 \%$ are neutral. This proves the young Indonesians are cooler with his personal world than thinking about the fate of his country. Whereas in fact there are still many things related to the problems that occur in the nation of Indonesia is the responsibility. The disease of youth or other adolescents is pornography. More than 50 porn videos were created and released in Indonesia. Most amateur video recording camera phone. And worse as many as $90 \%$ of pornographic video makers come from among young people. Thus the results of a Sony Set research. Television practitioner and author of the book titled "500 plus, Wave Video Porno 
Indonesia". Not to mention the action of fighting among teenagers to premanisme on campus. Almost $75 \%$ of drug users are teenagers (15-25 years old). And free sex is free to roam among teenagers.

The above phenomenon illustrates the importance of rebuilding awareness of the soul and identity of this nation as a great nation and dignity so as not to lose the milestones of this nation's struggle. The need for orientation to the values of the Bhineka's that is contained in the philosophy of Pancasila and the motto of Bhineka Tunggal Ika (Unity in Diversity) is the consideration of the authors in this research based on the concern about the condition of identity and nationalism generation awareness of this generation of fading future. Through research conducted on the students of Pancasila and Citizenship Education Studies program this study is expected to contribute to the strengthening of the soul and national identity among students in particular.

Based on the above considerations and descriptions, the researcher conducts research entitled "Reorientation of Values of the Indonesian Diversity to the Reaffirming the National Identity" (Descriptive Study to Students of Citizenship Education Program at Indonesia Education Institute of Garut). With consideration of the title is operationally formulated in the form of questions, among others: 1) How media literacy in learning Pancasila and Citizenship education for Students in the frame of diversity of Indonesia, 2) How to Integrate the values of Pancasila in the motto of the Indonesian Dynasty, 3) How Integration of cultural values local in learning Pancasila Education in strengthening the identity of nationalism in diversity Indonesia.

\section{THEORETICAL REVIEW}

\section{A. Reorientation of the Diversity Values of Indonesian}

Social or cultural change is a phenomenon that occurs throughout the history of human life. Change is the primal experience of life, a basic experience entirely new in the history of mankind - not simply change, but change at increasing rapidation. Diversity, plurality and heterogeneity is one form of change both socially and culturally which is one of the causes is globalization in the sense that the era of society that has been global so that there is mixing of various types of activities both concerning personal or group even though they still have their own character and character. As the other explains alterations in social phenomena at various levels of human life, from the individual to the global. This indicates that sociologically or anthropologically that change will occur from time to time in human life. Traditional culture may turn into a modern culture adopted from an infinite form of global life.

Indonesia is a form of a very diverse nation (plural or Bhinneka), a slogan stuck in the paws of Garuda Birds since Indonesian independence has illustrated that the historical record of the birth of Indonesia is a composite country record, perhaps the world's nations realize that plurality will occur in this world, but Indonesia has long since before the birth of the proclamation declared this diversity of country.
Pluralism is a challenge for Pancasila and Citizenship Education (PPKn) as part of the transformation of character education. Based on that, Sumantri describes the alternative solution that the subject of matter in Pancasila and Citizenship Education must be interdisciplinary, so that the experts and educators understand social issues comprehensively. In addition to the above in the challenges of the century now, the teaching methods that should be used in the present era, which is to create a democratic climate within the classroom and lessons oriented on social issues [4].

Of course the necessary of material is that oriented to the values, morals, social environment, and individual responsibility as a citizen. A workable approach as described above is with a multicultural approach based on a global perspective. Concerning Pancasila and Citizenship Education which is a study of Social Studies NCSS asserts that "Social studies programs should include experiences that provide for the study of culture and cultural diversity", and Refer to Dewey's opinion "education should prepare the next generation to live and function in a pluralistic society "Then what is needed to answer that challenge is to create a learning process that refers to the understanding of cultural differences. For this reason, multicultural education is needed to give students an understanding of the differences in culture.

Referred to purpose of the Pancasila and Citizenship Education trying to create human having intellectual skill and social skills. Then the Pancasila and Citizenship Education which emphasizes on the effort of forming good citizenship with democratic color deserves to be adhesive tool to plurality of Indonesian. Civics as one of the elements in education in the country has the eternal goal of educating to be a good Citizenship [5]. Pancasila and Citizenship Education itself is the selection and reconstruction of educational disciplines, and the disciplines of social sciences, humanities, organized and presented psychologically and scientifically for educational purposes [4]. Study Program of Pancasila and Citizenship Education has the role and responsibility to nurture students or students as the generation of nation to have competence as a good citizen able to live in pluralism and diversity so as to realize unity in diversity of Indonesia.

Based on upon, Pancasila and Citizenship Education has the broad scope study and very noble purpose of developing citizenship competence, namely civic knowledge, civic skills and civic disposition, into a unity in shaping national identity to form the Indonesia character. Through the model and learning strategy that leads to a humanist and constructivist democratic climate, lecturers must strive to foster the values of the characters contained in Pancasila and the motto of Bhinneka Tunggal Ika as the Indonesian character. The skills of lecturers or educators in training and developing democratic attitudes are the main strategies that seek to develop attitudes toward this multicultural and diversity.

\section{B. The Strengthening of Identity and Nationality of Indonesia}

The development of national consciousness has a meaning to rebuild our nationalism foundation (Nation character building). Nation building in principle an ongoing process towards the creation of a state in performing its duties on the 
basis of its ideology [6]. In other words, nation building is the process of forming the unity of a whole nation. Meanwhile, the nation itself refers to a community as a unity of common life that encompasses different elements in ethnic, class or social class, belief, culture, linguistic, and so on. All of them are integrated in historical development as the unity of the political system based on solidarity supported by the common will. Heterogeneity in various aspects of life, its elements are galvanized into a political homogeneity and is commonly manifested as a national state. The national state itself becomes a vehicle that serves to adapt, maintain its unity, strengthen its integration process and achieve its purpose of existence. The national state is more effective and efficient in sustaining the existence of a pluralistic group than as a local, regional, tribal, communal, So in the development of a nation, the integration process becomes a central issue, meaning territorial integration and socio-political integration are the dominant factors in realizing national units as they are today [3]

The growth of a sense of nationalism that occurred. The occurrence of socio-cultural changes caused two factors the following:

1) Internal factors, internal factors are factors that come from within society itself. These factors are as follows.

- Increasing and Diminishing Population

- New Invention (Innovation)

- Conflict Occurring in Society

- Rebellion and Revolution

2) External Factors, external factors are factors that come from outside the community that can lead to socio-cultural changes. These factors are as follows.

- Natural Change

- War

- The Influence of Other Cultures

It also appears that nationalism in Indonesia is a living thing, which moves continuously dynamically along with the development of society, even today. The meaning of nationalism itself is not static, but dynamic follows the rolling of society in time. Nation is derived from the Latin nation, developed from the word nascor (I was born), then at the beginning of nation (nation) is interpreted as "a group of people born in a same area". The word 'nationalism' according to Abbe Barruel was first used in Germany in the fifteenth century, which is intended for students who come from the same area or speak the same language, so they (in new and new campuses) still show their love against their nations/tribes of origin [7]. Nationalism was originally associated with the love of a group of people in the nation, language and origin region. Such love is called patriotisms today. So at first nationalism and patriotism were just as meaningful.

But since the French revolution erupted 1789, the notion of nationalism experienced various understandings, because the conditions underlying it vary widely. Between one nation and another nation. Nationalism is no longer a product of European enlightenment but a label of struggle in the western Asian-
African countries. The diversity of meaning can be seen from the following opinions. Smith interpreted nationalism as an ideological movement to achieve and maintain autonomy, cohesion and individuality for a particular social group recognized by some of its members to shape or determine a true or potential nation [8]. Snyder meanwhile interpreted nationalism as a powerful emotion that has dominated the minds and political actions of most people since the French revolution. It is not a natural, but a historical phenomenon, arising in response to certain political, economic and social conditions. Meanwhile, Carlton Hayes, as quoted Snyder distinguishes four meanings of nationalism [9]:

- As the actual historical process, namely the process of history of the formation of nationality as political units, the formation of tribes and the institutional empire of the modern national state.

- As an ideal theory, principle or implication in the actual process of history.

- Nationalism cares for political activities, such as the activities of certain political parties, the incorporation of historical processes and a political theory.

- As a sentiment, which denotes a state of mind between one nationalities.

Meanwhile Benedict Anderson defines nation (nation) as an imagined political community and imagined as both inherently limited and sovereign) [10]. The term imagined is important, according to Anderson, given that members of the nation have mostly never met each other, but at the same time in their minds a shadow lives that they are in a certain communitarian unit. Because living primarily in the shadow (in the positive sense) of humanity who is also alive and dynamic, nationalism is here understood as something living, which continues to dynamically experience the tidal process, up and down. Such a view presupposes that nationalism is a living thing, which dynamically evolves and seeks new forms according to the development and demands of the times. Shafer says that nationalism is multi-meaning, it depends on the objective and subjective conditions of each nation. Therefore, nationalism can be meaningful as follows [11]:

- Nationalism is a love of the same country, race, language or culture, then in this case nationalism is equal to patriotism.

- Nationalism is a desire for political independence, salvation and prestige of the nation.

- Nationalism is a mystical service to a vague, sometimes even supernatural, social organism called a nation or Volk whose unity is superior to its parts.

- Nationalism is a dogma that teaches that individuals only live for nation and nation for the sake of the nation itself.

- Nationalism is a doctrine which states that its own people must be dominant or highest among the Gentiles and must act aggressively. 
Despite the various definitions of nationalism, Hans Kohn underlines that the essence of nationalism is the same, namely "a state of mind, in which the supreme loyalty of the individual is felt to be due to the nation state [12]. Thus that nationalism is a mental force of psychology that manifests in the love of the nation against his country.

\section{RESEARCH METHOD}

The method used in this research is explanatory survey method (explanatory survey method) with quantitative approach. This research used survey method because the data collected were sourced from samples taken from the student population of PPKn Institut Pendidikan Indonesia. Explanatory Survey Method is used to explain and describe the answers of respondents, then tested the relationship between research variables based on empirical data. By processing the main data obtained by spreading the questionnaire or questioner to 40 sample of research that is student of level 1 semester 2 . The data which is described by using descriptive analysis are three problem formulation, among others about (1) the use of Media Literacy in learning of Pancasila Education, (2) Integration of Pancasila and Dhinekaan values in each taught material, (3) Elaboration of Pancasila Values and Local Culture in student life with its environment. To describe the overall data of contribute causality from variable $\mathrm{X}$ with variable $\mathrm{Y}$, then used correlation test with simple linear tested by SPSS 21 . The objective to be achieved in explanatory survey method is to test (verify) factual propositions, meaning deduction propositions (hypothesis) is tested empirically.

\section{RESUlt AND DisCUSSION}

Based on descriptive analyze show that cumulatively from 5 question items developed illustrated that the use of information technology or media literacy in learning Pancasila and Citizenship Education by lecturers shows 1) in learning Pancasila Education lecturers always integrate learning technology more use power point $(75,65$ percent of respondents), 2) lecturers understand the use of information technology in learning Pancasila Education (75.2 percent), 3) Direct students use technology wisely in life (75.6 percent), 4) Integrate positive technology values especially Mobile and social media (75.3 percent) and the use of information technology should always integrate Pancasila and Diversity values (76.5 percent). Thus, for the first research formulation the average respondent stated that the use of media technology based on social media wisely and wisely by integrating the values of Pancasila will teach the understanding of the Bhineka's, 75.5 percent of respondents said it will be effective and good for learning Pancasila and Citizenship Education.

Based on the results of descriptive data processing for the formulation of the integration of values of Pancasila and Citizenship Education can be explained as follows: 1) Lecturers always integrate the values of Pancasila in learning (64.3 percent), 2) Pancasila values are taken from the relevance of daily life (65.7 percent); 3) Pancasila values teach very high diversity values (65.89 percent); 4) Lecturers always remind the values of diversity taught in Pancasila and Citizenship Education (65.5 percent) and 5) if the lecturers integrate and teach the diversity values will be increasingly recognized the importance of mutual respect for diversity (67.5 percent). Cumulatively descriptive, the integration of Pancasila values in each taught material will have a positive impact on the development of tolerance in people's lives.

The result of the data processing description of the integration of local cultural wisdom in Pancasila learning shows that 1) Teaching diversity is the value of local culture that has been embedded in the soul of the Indonesian nation (80.2 percent); 2) Pancasila teachings percent are the embodiment of the Diversity of Indonesia (85 percent) , 3) All the values of Sila Pancasila have depicted elements of local Indonesian culture (86 percent), 4) excellent local value integration in elaboration with Pancasila values (85.6 percent), 5) Local Cultural Values become a treasure for Pancasila power as the philosophy of the Indonesian nation $(85.57$ percent). The cumulative description that the element of local culture has become the soul and philosophy of the formulation of Pancasila from sila to 1 to sila to 5, so that if done optimally by lecturers and students then the integration of media, Pancasila and Local Culture into a unity complement each other comprehensively as an embodiment character of the Indonesian nation.

The result of correlation test of Diversity learning value by integrating media technology, Pancasila and Local Culture values to strengthening national identity by using simple linear regression test result has correlation significantly equal to 698 coefficient of correlation or equal to 69,8 percent. Thus it can be stated that by teaching the value of diversity by integrating media literacy, the value of Pancasila and local culture will give the strengthening of nationalism identity by 70 percent.

Related to the results of this study, that national identity or national identity will be stronger when all elements have a desire of unity and unity. J.Ernest Renan who adheres to the flow of nationalism based on the human factor, suggests that the emergence of a nation because of the will to unite (one unity vote). While Otto Bouwer reveals that the feelings of nationality arise because of equality of behavior and behavior in the fight for unity and common fate. Both argue that nationalism arises due to humanitarian factors, but both provide different pressures. First, J. Ernest Renan emphasizes the factor of fate equation, while Otto Bouwer outlines the equation of fate. Secondly, with the difference in pressure then the conclusions about nationalism are also different. According to J. Ernest Renan, a nation arises from a drive of will (for example the United States); while Otto Bouwer, a nation arising from the experience of suffering, misery, and bitterness of the same life. Examples such as nationalism in Asian and African countries; arise due to the fate of fate as a colonized nation [13].

The Renan theory says that ethnicity is not necessary for the rise of nationalism, so nationalism may be in a multiethnic community, religious unity is also not necessary for the rise of nationalism. Language unity facilitates the development of nationalism but is not absolutely necessary for the rise of nationalism. In terms of nationalism, the absolute and ultimate requirement is the willingness and determination together [14].

Therefore, it is true what Soekarno affirmed when quoting Ernest Renan: 
"Nationalism! To be a nation! It was no later than the year 1882 that Ernest Renan published his idea of concept of nationhood".

"Nationhood", according to this author is a spirit of life, an intellectual principle arising from two things: firstly, the people in former times had to be together to face what came, secondly, the people now must have the will, the wish to live and be one. Not race, nor language, nor religion, nor similarity of needs, nor the borders of the land make that nation.

Nationalism is a discourse to sue the identity of the colonialists, renew the new self-consciousness, and negotiate new patterns of relations (with "colonizers") based on the new self-consciousness. Nationalism is a socio-cultural-political strategy used as a vehicle to fight imperialism.

\section{CONCLUSION AND RECOMMENDATION}

The destiny of Allah and the historical record of the Indonesian Nation has implied and explicitly stated that Indonesia is pluralism country. As this extraordinary gift, the people of Indonesia must defend it as proof of responsibility to God and this State. It can be concluded that in particular to ensure the preservation of values of diversity in the Indonesian nation, the student as an agent of reform through his education must always keep it. 1) the wise use of technology media by integrating the values of Pancasila and Diversity and local culture of Indonesia will be able to provide benefits to the love of the Indonesian nation to his country, 2) Diversity values contained in the philosophy of Pancasila is a value that cannot be separated in every learning Pancasila and Citizenship Education so that lecturers should always integrate in every learning, 3) the value of local culture is the wealth of the Indonesian nation that should be the backbone of the strong values of life in the soul of the Indonesian nation.
Based on that, the students, lecturers and all elements of society must realize that the values of diversity is a form of the birth of NKRI which must always be a force for the upholding of the nationalism spirit of the Indonesian Nation.

\section{REFERENCES}

[1] N. Majid, Multidimensi Pembangunan Bangsa: Etos Nasionalisme dan Negara Kesatuan, Yogyakarta: Penerbitan Kanisius, 1999.

[2] L. Pedersen, "Religious Pluralism in Indonesia", The Asia Pacific Journal of Anthropology, vol. 17, No.1, Oct 2016.

[3] S. Kartodirdjo, Pengantar Sejarah Indonesia Baru: Sejarah Pergerakkan Nasional dari Kolonialisme sampai Nasionalisme, Jakarta: PT Gramedia Pustaka Utama, 1992.

[4] N. Sumantri, Menggagas Pembaruan Pendidikan IPS, Bandung: Rosdakarya Remaja, 2001

[5] S.P. Wronski, Social Studies and Social Sciences: A Fifty-Year Perspective, Bulletin No. 78, 1986.

[6] T.B. Simatupang, Peranan Angkatan Perang dalam Negara yang Membangun, Jakarta: Yayasan Idayu, 1980.

[7] H. Ritter, Dictionary of Concepts in History, New York: Greenwood Press, 1986

[8] A.D. Smith, Nationalist Movement, London: The Macmillan Press, 1979.

[9] A. Benedict, Imagined Communities: Reflection on the Origin and Spread of Nationalism, Yogyakarta: Pustaka Pelajar \& Insist Press, 2002.

[10] L.L. Snyder, The Dynamic of Nationalism, Princeton: D. Van Nostrand Co. Inc, 1964

[11] B. Wardaya, "Nasionalisme Universal: Menjawab Ajakan "Pasca Nasionalis"nya Romo Mangun", Jurnal Iman, Ilmu, Budaya, vol. 3, September. 2002, Jakarta: Yayasan Bhumi Aksara

[12] B.C. Shafer, Nationalism Myth and Reality, New York: A Harvest Book Harcourt, 1955.

[13] H. Kohn, Nasionalism Its Meaning And History, Florida: Robert E. Krieger Company, 1984

[14] E. Renan, Apakah Bangsa Itu? C.F.G. Sunaryati Hartono (ed.), Bandung: Alumni, 1994. 